\title{
A STUDY THE BUYER BEHAVIOUR TOWARDS SMALL CARS PRODUCED BY MARUTI SUZUKI INDIA LIMITED IN THE NILGIRIS DISTRICT OF TAMIL NADU
}

\section{A. JAGANATHAN}

Head \& Assistant Professor, Department of Management with CA, Bharathiar University Arts \& Science College,

Gudalur, Nilgiris, Tamil Nadu, India

\begin{abstract}
The study of buyer behaviour focuses on how individuals make decisions to spend their available resources (time, money, effort) on consumption-related items. That includes what, why, when, where, how often they buy it, how they evaluate it after the purchase and the impact of such evaluation on future purchase. More than ever before, the need to understand buyer and customer behaviour has become a hot topic around the globe. The study of buyer behaviour includes an analysis of awareness of the customers, factors that influence purchase decisions, buyer satisfaction, and problems faced by the buyers. Understanding how a buyer makes purchase decisions can help marketing managers in several ways.

KEYWORDS: Automobile, Behaviour, Passenger Vehicle \& Satisfaction
\end{abstract}

Received: Sep 18, 2018; Accepted: Oct 09, 2018; Published: Nov 10, 2018; Paper Id.: IJHRMRDEC20188

\section{INTRODUCTION}

India represents one of the world's largest car markets. Easy availability of finance and rising income levels are encouraging the middle-class population to choose from the vast range of passenger vehicles. The Indian auto industry has been recording tremendous growth over the years and has emerged as a major contributor to India's gross domestic product (GDP). The industry currently accounts for almost 7 per cent of the country's GDP and employs about 19 million people both directly and indirectly.

In addition, with Government's backing and a special focus on exports of small cars, multi-utility vehicles (MUVs), Two-wheelers and Three-wheelers and auto components, the automotive sector's contribution to the GDP is expected to double reaching a turnover worth US\$ 145 billion in 2016, according to the Automotive Mission Plan (AMP) 2006-2016. The Foreign Direct Investment (FDI) impact on the growth of Automobile Industry is visible across the spectrum of this sector-direct employment in manufacturing, auto component suppliers and auto service segments. In the growth aspect, it is distinctly discernible in the passenger vehicle segment.

After economic reforms took place in India in 1991, it is only in the mid-1990s, that the automotive industry started opening up. Thus, the mid-1990s are characterized by the entry of global automotive manufacturers through joint ventures in India. Till the 1990s, the automotive industry in India was primarily dominated by Maruti Suzuki, Tata Motors, Hindustan Motors and Premier Padmini in the passenger car segment. 
Ashok Leyland, Tata Motors and Mahindra \& Mahindra dominated the commercial vehicle segment while Bajaj Auto dominated the two-wheeler segment. Eventually multinational automakers, such as, though not limited to, Suzuki and Toyota of Japan and Hyundai of South Korea, were allowed to invest in the Indian market ultimately leading to the establishment of an automotive industry in India. A number of foreign firms also initiated joint ventures with Indian companies.

\section{Statement of the Problem}

In this backdrop, a study on the buyer behaviour towards small cars is the most important for the car manufactures. Such an analysis will provide car manufacturers, a quantitative estimate of level of satisfaction being perceived by the customers. Therefore, in this study an attempt has been made to seek answers to the research questions such as how are the buyers satisfied with the price, fuel efficiency, maintenance, after-sale services and overall product features of the small cars in the study area? and what are the factors that influence the customers. Hence, in the present study, an attempt has been made to analyze the variables that affect the buyer behaviour towards small cars particularly the small cars manufactured by the Maruti Suzuki India Limited in the Nilgiris district of Tamil Nadu.

\section{Objectives of the Study}

- $\quad$ To analyze the buyer behaviour towards small cars produced by Maruti Suzuki India Limited.

- To analyze the perceptions and expectations of the customers about service quality of the authorized dealers in the study area.

- To offer some viable and practicable suggestions to the car manufacturers to increase customer satisfaction and to improve their market share in the competitive business environment.

\section{Research Methodology}

The study analyzes the buyer's behaviour towards small cars and perceptions of the customers about service quality of the authorized dealers in Nilgiris district of Tamilnadu. Survey method has been used to fulfill the objectives of the research.

\section{Sample Size}

\section{Sampling Technique}

In this study, the researcher adopted a sampling technique where the population is based on easy availability. This sampling method is called convenience sampling. The researcher selected simple random sampling because of the time limitations in data collection. A sample of size 300 is taken for this study.

\section{Method of Data Collection}

In this study, the researcher uses two methods for data collection. They are Primary data collection and Secondary data collection

\section{Statistical Tools}

The statistical tests used in the study include, Simple Percentage, Mean, and Standard Deviation, t-test, Chi-square test, Correlation matrix. SPSS (Statistical Package for Social Sciences) version 16.0 was used to compute and 
analyze the data.

\section{Hypothesis}

- There is no significant difference between region-wise distribution of the respondents and their level of perception about overall service quality.

- There is no relationship between perceived value of the service quality dimension such as tangible, reliability, responsiveness, assurance, empathy and perceived value of overall service quality.

- There is no significant difference between demographic variables and level of perception about service quality.

\section{Limitation of the Study}

- The study was carried out in Nilgiris district of Tamilnadu. Thus, its finding cannot be generalized to other areas due to geographical variation and customers preferences.

- The study is purely based on the customer's opinion. The researcher felt that the customer might express a biased opinion, which may limit the validity of the study.

- Respondents' opinion may change from time to time and the responses are subject to variation depending upon the situation and the attitude of the respondents at the time of the survey.

\section{REVIEW OF LITERATURE}

Park and Srinivasan, (1994) conducted a study on various car models in European market and concluded that brand equity should be evaluated in terms of consumer knowledge, familiarity, and associations with respect to the brand.

Achuthan (1996) analyzed the impact of advertisement on consumers in buying cars. The study also aimed to know the media influence on such preferences. The study revealed that the consumers are very much influenced by the advertisements and in this process newspaper media is found to be a significant player. The study also revealed that the consumers are satisfied with the information given in the advertisements.

Karthigai Prakasam (1998) argued that the major reasons for selecting the small cars were affordable price, appearance and mileage. Further, the study revealed that the friends influence the decision on purchase.

Clive et al. (2003) stated that, the automotive industry, accustomed to addressing customer expectations with a response that calls for meeting average rather than specific customer demand, finds itself unable to respond adequately to raised customer expectations and individual demands. To fill the gap between what customers want and what has actually been produced, the manufacturers hold a large supply of vehicles in inventory - to give the customer a so-called choice of make, colour, and options packages - and rely on ever more costly sales incentives to help boost demand. While these initiatives promise cost savings and faster response to the individual customer, they fail to address the entire customer lifecycle ownership experience. To foster brand loyalty, vehicle manufacturers must now work to improve the customer experience by adopting state-of-the-art, proven customer relationship management systems and processes.

Ramkumar (2004) his study revealed that most of the respondents are aware of many of popular brand of passenger cars. The customers give more importance to fuel efficiency than other factors. They believe that brands name tell something about product quality, utility, technology and the like. The consumer prefers to purchase the passenger cars, 
which offers high fuel efficiency, good quality, technology, durability and reasonable price.

Sangeetha (2004) selected a sample of 300 respondents was selected and used simple percentage test for her study. The study revealed that "the manufactures must pay equal attention to the colour, price and technology to create long-lasting impression in the consumers mind.

Varshney (2006) the primary data regarding consumer perception was collected from a sample of 300 respondents revealed that the consumer perception positively affects marketing trends of cars. Hence the companies are marking their utmost effort to market the cars which are perceived by the consumers. There is a need to translate the suggestions referred to as above into practice so that consumers 'perception might be converted into consumer's delight and companies might stand to the force of worldwide competition.

Rani (2008) studied the passenger car industry in India. Trends in car industry had been studied prior to liberalization and post-liberalization. After liberalization, the passenger car industry in the nineties was characterized by an increase in the number of brands available in the market, which caused brands to compete on the basis of product features.

Goyal, et al (2008) attempted to find the relative importance of various factors that attract the customers while selecting a particular car in its segment. The study revealed that in the case of purchase of luxury cars, the factors like horse power, model, luggage capacity, accessories and loan facility emerged as the most significant factors, in case of medium cars, after-sales service, availability of spare parts, model, shape and engine capacity were important and in the case of small cars, the factors like accessories, engine capacity, after-sales service and price were main considerations.

Natarajan (2010) studies consumer preference of global brands and local brands in the Indian car industry. Consumer brand perceptions have substantial implications in Marketing. The customers' preference towards local and global brands is studied by administering a structured interview schedule with 150 customers in Pondicherry city. The findings of the study advised that the consumers who possessed global car brands, preferred their car brands due to factors such as global presence, worldwide reputation and quality of being a foreign made. Consumers made favorable perceptions about the countries, wherein they tend to associate factors such as superior quality, technical advancements, modernization etc. to the country from which the brand had taken its origin. Consumers who owned a local brand evaluated the local brand in a favorable manner, wherein they tend to associate the brand to India's strong automobile sector that makes quality and technically efficient cars.

Alberto montanari (2010) in his article on "small segment to the force" revealed that " affordable entry" - level cars, the pro-life ration of second - hand cars and easy financing did succeed to some extent in weaning customer away from two - wheelers. But on the basis of price alone, two wheelers will continue to compete with affordable cars. To raise the share of passenger cars in the market, passenger car attributes such as comfort, fulfillment of aspirations and value for money will need to register favorably in the customers mind".

Vidyavathi (2012) the study throws light on various aspects that the manufactures should concentrate on to attract the prospective buyers. The demand for the small Automobile segment is increasing because of the growing number of nuclear families as well as parking problems. Hence the manufactures should find out the needs, wants, tastes and preferences of consumers in order to design the products. Also fuel economy and driving comfort are the most important parameters followed by availability of spares and their price. 
Shiv Prasad Joshi (2013) ascertained that currently the small car industry in India is dominated by Maruti. Key finding which emerged for this study is that Alto is most preferred car in this segment followed by Santro, Tata Indica, Maruti Zen, Spark whereas Palio is least preferred car among the consumers. This study reveals that purchasing of car is strongly influenced by the advertisements and secondly by family and friend's recommendations. In addition, when researchers measured the level of satisfaction, it revealed that nearly fifty percent of consumers are fully satisfied from their brand while around sixteen percent of respondents are not satisfied from their purchasing decision. The study also reveals that price is one of the most important criteria in selection of car. Safety measures in car are least preferred criteria. At the same time companies must pay attention to fuel efficiency, warranty and after-sale services and availability of accessories.

Elizabeth Chacko, et al (2014) concluded that there may be a number of factors which are responsible for the changing purchase preference of the consumer in four-wheelers. Among those variables - Safety, Maintenance, Mileage, Easy mode of financing and easy driving are found to be pointed influencing buying preference of consumers. With the rapid and consistent growth in the price of the fuel consumers are more conscious about mileage. So they highly prefer mileage while buying a car. This study found that consumers also prefer easy mode of financing a car. With the growing competition in automobile sector, companies are providing easy financing facility to grab maximum of consumers. This allows consumers from a middle income group to conveniently own a car by giving easy installments which is also forcing consumers to buy a car. Lastly, it was found that consumers also prefer model while purchasing a car.

\section{ANALYSIS AND INTERPRETATION}

\section{Sexwise Distribution of the Respondents}

\section{Table 1}

\begin{tabular}{|c|l|c|c|}
\hline S. No & Sex & No. of Respondents & Percentage \\
\hline 1 & Male & 249 & 83.00 \\
\hline 2 & Female & 51 & 17.00 \\
\hline \multicolumn{2}{|c|}{ Total } & $\mathbf{3 0 0}$ & $\mathbf{1 0 0 . 0 0}$ \\
\hline
\end{tabular}

Source: Primary data

It is observed from table 1 that out of 300 respondents, more than three-fourth of the respondents are male and nearly 17 per cent are female. The table reveals that due to availability of employment opportunities and prosperous agricultural activities in study area significant portion of male and female have purchased small cars in the study area.

\section{Age-Wise Distribution of the Respondents}

Table 2

\begin{tabular}{|c|c|c|c|}
\hline S. No & Age & No. of Respondents & Percentage \\
\hline 1 & Below 40 years & 56 & 18.67 \\
\hline 2 & $40-50$ years & 164 & 54.67 \\
\hline 3 & Above 50 years & 80 & 26.66 \\
\hline \multicolumn{2}{|c|}{ Total } & $\mathbf{3 0 0}$ & $\mathbf{1 0 0 . 0 0}$ \\
\hline
\end{tabular}

Source: Primary data

Table 2 shows that out of 300 respondents, about 55 per cent of the respondents are in the age group of $40-50$ years followed by nearly 27 per cent of the respondents who are in the age group of above 50 years, about 19 per cent of the respondents fall in the age group of below 40 years. From the table it is understood that the buyers who are above the age of 40 years mostly purchase the small car in the study area. 
Source of Finance of the Respondents

Table 3

\begin{tabular}{|c|l|c|c|}
\hline S. No & \multicolumn{1}{|c|}{ Source } & No. of Respondents & Percentage \\
\hline 1 & Loan from financial institutions & 21 & 07.00 \\
\hline 2 & Self finance & 84 & 28.00 \\
\hline 3 & Both & 195 & 65.00 \\
\hline \multicolumn{2}{|c|}{ Total } & $\mathbf{3 0 0}$ & $\mathbf{1 0 0 . 0 0}$ \\
\hline
\end{tabular}

Source: Primary data

It observed from the table 3 that out of 300 respondents nearly 65 per cent of the respondents source of finance is both self-finance and loans from financial institutions to buy small cars and 28 per cent of the respondents exclusively used their own money to purchase the car and 7 per cent of respondents wholly depend financial institutions to buy a small car. Therefore, it can be inferred from the table that financial institutions, which provide car loans, dominate the small cars segment industry in the study area.

\section{Level of Satisfaction with Fuel Efficiency}

Table 4

\begin{tabular}{|c|l|c|c|}
\hline S. No & Level of Satisfaction & No. of respondents & Percentage \\
\hline 01 & Highly satisfied & 12 & 4.00 \\
\hline 02 & Satisfied & 18 & 6.00 \\
\hline 03 & Average & 24 & 8.00 \\
\hline 04 & Dissatisfied & 180 & 60.00 \\
\hline 05 & Highly dissatisfied & 66 & 22.00 \\
\hline \multicolumn{2}{r}{ Total } & $\mathbf{3 0 0}$ & $\mathbf{1 0 0 . 0 0}$ \\
\hline
\end{tabular}

Source: Primary data

Table 4 shows that out of 300 respondents the majority of the respondents are dissatisfied of which 22 per cent of the respondents are highly dissatisfied and only 10 per cent of the respondents are satisfied with the fuel efficiency of the small car owned by the respondents. Therefore, it can be inferred from the table that customers are not satisfied with fuel efficiency of the small cars as stated by the dealers in the study area.

\section{Demographic Variables and Level of Satisfaction with Price of the Car}

\section{Null Hypothesis}

There is no significant difference between demographic variables and level of satisfaction with price.

\section{Chi-Square Test Result}

Table 5: Chi-Square Test Result

\begin{tabular}{|c|l|c|c|c|c|}
\hline $\begin{array}{c}\text { S. } \\
\text { No }\end{array}$ & \multicolumn{1}{|c|}{ Variable } & $\begin{array}{c}\text { Chi-Square } \\
\text { Test - Value }\end{array}$ & $\begin{array}{c}\text { Table value } \\
\mathbf{5 \%} \text { level }\end{array}$ & $\begin{array}{c}\text { Table value } \\
\mathbf{1 \%} \text { level }\end{array}$ & Result \\
\hline 1 & $\begin{array}{l}\text { Sex and Level of satisfaction } \\
\text { with price }\end{array}$ & 57.10 & 9.49 & 13.23 & $* *$ Significant \\
\hline 2 & $\begin{array}{l}\text { Age and Level of satisfaction } \\
\text { with price }\end{array}$ & 10.60 & 15.51 & 20.09 & Not significant \\
\hline 3 & $\begin{array}{l}\text { Educational Qualifications and } \\
\text { Level of satisfaction with price }\end{array}$ & 51.70 & 21.03 & 26.22 & $* *$ Significant \\
\hline 4 & $\begin{array}{l}\text { Occupation and Level of } \\
\text { satisfaction with price }\end{array}$ & 53.80 & 21.03 & 26.22 & $* *$ Significant \\
\hline
\end{tabular}




\begin{tabular}{|c|l|c|c|c|c|}
\hline \multicolumn{9}{|c|}{ Table 5: Contd., } \\
\hline 5 & $\begin{array}{l}\text { Income and Level of } \\
\text { satisfaction with price }\end{array}$ & 12.1 & 15.51 & 20.09 & Not significant \\
\hline 6 & $\begin{array}{l}\text { Marital status and Level of } \\
\text { satisfaction with price }\end{array}$ & 49.20 & 9.49 & 13.23 & $* *$ Significant \\
\hline 7 & $\begin{array}{l}\text { No. of family members and } \\
\text { Level of satisfaction with price }\end{array}$ & 23.10 & 15.51 & 20.09 & $* *$ Significant \\
\hline 8 & $\begin{array}{l}\text { Place of residence and Level of } \\
\text { satisfaction with price }\end{array}$ & 30.80 & 9.49 & 13.23 & $* *$ Significant \\
\hline
\end{tabular}

** Significant at $5 \%$ level and $1 \%$ level

Table 5 reveals that there is a significant difference between Sex and Level of satisfaction with price, Educational Qualifications and Level of satisfaction with price, Occupation and Level of satisfaction with price, Marital status and Level of satisfaction with price, Number of family members and Level of satisfaction with price and Place of residence and Level of satisfaction with price of the small car. However, there is no significant difference between Age and Level of satisfaction with price and Income and Level of satisfaction with price of the small car.

Perception and Expectation on Tangibles

Table 6

\begin{tabular}{|c|l|c|c|c|c|c|}
\hline \multirow{2}{*}{$\begin{array}{c}\text { S. } \\
\text { No }\end{array}$} & \multicolumn{1}{|c|}{ Parameters } & \multicolumn{2}{c|}{ Perception } & \multicolumn{3}{c|}{ Expectation } \\
\cline { 3 - 7 } & \multicolumn{1}{|c|}{$\begin{array}{c}\text { Mean } \\
\text { Score }\end{array}$} & $\begin{array}{c}\text { Mean } \\
\text { Score (\%) }\end{array}$ & $\begin{array}{c}\text { Mean } \\
\text { Score }\end{array}$ & $\begin{array}{c}\text { Mean } \\
\text { Score (\%) }\end{array}$ & $\begin{array}{c}\text { Service } \\
\text { Quality Score }\end{array}$ \\
\hline 01 & $\begin{array}{l}\text { The dealers have up-to-date } \\
\text { equipments }\end{array}$ & 6.73 & 96.14 & 5.80 & 82.85 & 0.93 \\
\hline 02 & $\begin{array}{l}\text { Dealers' office physical facilities are } \\
\text { visually appealing }\end{array}$ & 6.47 & 92.42 & 4.98 & 69.85 & 1.49 \\
\hline 03 & $\begin{array}{l}\text { Dealers' employees are well dressed } \\
\text { and appear neat }\end{array}$ & 6.12 & 87.42 & 5.14 & 73.42 & 0.98 \\
\hline 04 & $\begin{array}{l}\text { The appearance of the physical } \\
\text { facilities of the dealers is in keeping } \\
\text { with the type of services provided }\end{array}$ & 4.68 & 66.85 & 6.84 & 97.71 & -2.16 \\
\hline \multicolumn{2}{|l}{ Overall (N=300) } & 23.92 & 85.42 & 22.76 & 81.28 & 1.16 \\
\hline
\end{tabular}

Source: Primary data

Table 6 reveals the mean score obtained by the respondents for service quality in respect of tangibles. The average score of total expectations is 22.76 and the overall perception score is 23.92. The score shows a 1.16 difference. It implies that the perception is higher than the expectations. The respondents have a negative gap score for one parameter, namely 'The appearance of the physical facilities of the promoters is in keeping with the type of services provided'. The overall service quality score indicates that the customers are satisfied with service quality in respect of tangible.

\section{Level of Perception about Reliability}

Table 7

\begin{tabular}{|c|l|c|c|}
\hline S. No & Level of Perception & No. of Respondents & Percentage \\
\hline 1 & Low & 158 & 52.67 \\
\hline 2 & Medium & 126 & 42.00 \\
\hline 3 & High & 16 & 5.33 \\
\hline \multicolumn{2}{|c|}{ Total } & $\mathbf{3 0 0}$ & $\mathbf{1 0 0 . 0 0}$ \\
\hline
\end{tabular}

Source: Primary data 
It is understood from the table 7 that the majority of the respondents perceived low, about 42 per cent of the respondents perceived moderate and 5 per cent of the respondents perceived high level of service quality in relation to reliability. It is inferred from the table that the dealers fail to provide services up to the expectations of the customers with regard to reliability.

\section{Income and Level of Perception}

Table 8

\begin{tabular}{|c|c|c|c|c|c|}
\hline \multirow{2}{*}{$\begin{array}{l}\text { S. } \\
\text { No }\end{array}$} & \multirow{2}{*}{ Monthly Income } & \multicolumn{4}{|c|}{ No. of Respondents } \\
\hline & & Low & Medium & High & Total \\
\hline 1 & Below & $\begin{array}{c}29 \\
(15.59)\end{array}$ & $\begin{array}{c}13 \\
(14.94)\end{array}$ & $\begin{array}{c}10 \\
(37.03)\end{array}$ & $\begin{array}{c}52 \\
(17.30)\end{array}$ \\
\hline 2 & $50,000-75,000$ & $\begin{array}{c}127 \\
(68.29)\end{array}$ & $\begin{array}{c}28 \\
(32.18)\end{array}$ & $\begin{array}{c}12 \\
(44.46)\end{array}$ & $\begin{array}{c}167 \\
(55.66)\end{array}$ \\
\hline 3 & Above 75,000 & $\begin{array}{c}30 \\
(16.12)\end{array}$ & $\begin{array}{c}46 \\
(52.88)\end{array}$ & $\begin{array}{c}5 \\
(18.51)\end{array}$ & $\begin{array}{c}81 \\
(27.04)\end{array}$ \\
\hline & Total & $\begin{array}{c}186 \\
(100.00)\end{array}$ & $\begin{array}{c}87 \\
(100.00)\end{array}$ & $\begin{array}{c}27 \\
(100.00)\end{array}$ & $\begin{array}{c}300 \\
(100.00)\end{array}$ \\
\hline
\end{tabular}

Source: Primary Data, Figure in the Bracket Percentage of the Total.

Table 8 reveals that out of 186 respondents who perceived low level of perception, the majority of the respondents' monthly income is 50,000-75,000. About 16 per cent of the respondents' monthly income is above 75,000 and 16 per cent of the respondents monthly income is less than 50,000. Therefore, it can be inferred from the table that the middle -income group customers perceive poor service quality of the dealers in the study area.

\section{FINDINGS}

- The advertisements given on the television is the effective medium of advertisements to know about product features of the small cars in the study area.

- It is found that financial institutions, which provide car loans, dominate the small car segment industry in the study area.

- Most of the respondents in the study area are influenced by their family members to buy a small car of the company in the study area.

- The customers are satisfied with overall product features of the small cars manufactured by the company.

- The study indicates that some customers are satisfied with service quality in respect of tangible.

\section{SUGGESTIONS}

- The majority of the respondents' source of finance is loans from financial institutions to buy small cars. Therefore, the company should tie up with some good financial institutions to provide car loans with more installment payment facility and low interest rate to attract middle- class people in the study area.

- At present, the numbers of nuclear families are on the increase, so the car manufacturer should analyzes the need, want, taste, preference of the customer and design the product accordingly.

- To improve service quality the dealers of the company should give individual attention to their customers and understand the specific needs of their customers. 
- In order to give prompt services at the right time the company should increase more number of service centers in the study area.

\section{CONCLUSIONS}

The result of the study reveals that the customers are influenced by the factors like price, source of finance and awareness of the company. The study also reveals that the major problems of the customers are high price of the car, cost of fuel and high maintenance cost in the study area. It implies that service quality of the dealers in the study area needs improvements in service quality dimensions in order to fills the gaps that could lead to increased customer perception about service quality.

\section{REFERENCES}

1. Park, Chan S. and V. Srinivasan (1994), A Survey Based Method for Measuring and Understanding Brand Equity and its Extendibility, Journal of Marketing Research, 271-288, May 1994

2. Achuthan.P.” A Study on market for small cars in Coimbatote, unpublished thesis, Bharathiar Univeristy,1996

3. Karthigai Prakasam.C., Small cars- Consumer attitude towards brand preference”, unpublished thesis, Bharathiar Univeristy, 1998.

4. Clive, M. and S. Abraham. "Building Brand Loyalty by Improving the Customer Experience", Oracle Corporation on line catalog. pp: 3, 2003.

5. Ramkumar in "A study on brand preference passenger car with special reference to Coimbatore city", Indian Journal of Marketing”, Vol: XXXIV No.9 pp.10-15,2004.

6. V.Sangeetha, “A study on consumer post buying behaviour of four-wheeler with special reference to Tata products (cars)in Erode District”, unpublished thesis, Bharathiar University, Coimbatore, 2004.

7. Varshney “Consumer Perception and marketing trend of cars”, Southern Economist, Vol: 45, No: 15\&16, pp.51-54, 2006.

8. Rani, Sakthivel "Passenger Car Industry in India "Indian Journal of Marketing, Vol xxxviii, No. 11, pp. 36-42, 2008.

9. Goyal, B.B \& Aggarwal, Meghna, “Car Industry in India- An Analytical Study of Factors of Importance”, Indian Management Studies Journal, vol-12, No. 1, pp. 37-60, 2008.

10. Dr. P.Natarajan \& Thiripurasundari U, Local brand vs. Global brand syndrome $-A$ study with reference to Indian car industry, Advances in Management, Vol. 3, No:10, pp. 18-26, 2010.

11. Alberto montanari "small segment to the force”, The Hindu Survey of Indian industry, pp. 245, 2010.

12. K.Vidyavathi, "Customer Life Style Influence of Consumer Behavior with Reference to Automobile Industry in Chennai", Zenith International Journal of Multi disciplinary Research Vol.2, Issue 4, pp. 37-50, Apr 2012.

13. Shiv Prasad Joshi, “Consumer Behavior For Small Cars: An Empirical Study”, International Monthly Refereed Journal Of Research In Management \& Technology, Volume Ii, Pp. 47-52, February 2013.

14. Prof. Elizabeth Chacko and Ms. Punnya Selvaraj, "A study on buying behavioral pattern of Women drivers regarding B segment cars in Bangalore”, The International Journal Of Engineering And Science, Vol. 3, Issue 5, PP. 40-43, 2014. 
